\title{
Hybridní režimy jako svébytná kategorie politických režimů: Komparace vybraných př́stupü
}

\author{
Hybrid Regimes as an Independent Type of Political Regime: \\ A Comparison of Selected Approaches
}

\author{
JAROSLAV BÍLEK ${ }^{2}$
}

\begin{abstract}
The topic of bybrid regimes has always provoked heated debate. One of the reasons for this has been an often unclear and vaguely defined line between democracy and authoritarianism, which is why many theoretical concepts have come under heayy criticism. As a reaction to this frequent criticism, newer concepts have begun to appear - concepts which stem from a trichotomous classification of political regimes in an attempt to eliminate criticism and ambiguity. These new concepts see bybrid regimes as a stand-alone category of political regimes. The presented text aims at comparing the most well-known conceptions of bybrid regimes of this kind. Specifically, it deals with the conceptions of Mainwaring, Peréz-Liñan and Brinks; Levitsky and Way; Zinecker; Wigell; and Gilbert and Mohseni. On the basis of the comparison that was carried out, it is possible to conclude that in terms of practical use, each of these analyzed conceptions has its strengths and weaknesses. However, as far as contributions to the aforementioned debate are concerned, these concepts suffer from significant problems.
\end{abstract}

Keywords: Hybrid Regimes; Tutelary Regimes; Competitive Authoritarianism; Grey Zone; Non-Democracy

\footnotetext{
1 Tento text vznikl v rámci projektu Specifického výzkumu FF UHK Mezi demokracii a nedemokracii. Vybrané problémy studia bybridních rě̌imu. Za cenné připomínky děkuji Maxmiliánu Strmiskovi, Barboře Vališkové, Ondřeji Plachému a dvěma anonymním recenzentům

2 Interní doktorand, Katedra politologie, Univerzita Hradec Králové, Česká republika / Department of Political Science, University of Hradec Králové, Czech Republic. E-mail: bilek.jaroslav@uhk.cz.
} 


\section{1. Úvod}

Jednou z nejzajímavějších debat na poli výzkumu nedemokratických režimů je v posledních letech bezpochyby ta o hybridních režimech. Pravidelný čtenár odborných časopisů se díky ní mohl v posledních dvou desetiletích seznámit s množstvím textů, které se s daným tématem snažily vyrovnat. Zmíněné vyrovnání si potom každý z autorů a autorek vykládal a vykládá po svém, a tak lze $\mathrm{v}$ rámci uvedené diskuze sledovat práce, které nový směr výzkumu přijaly s povděkem a snaží se prohloubit poznání režimů v „šedé zóněcr3 (Carothers 2002), stejně jako četné polemiky a kritiky k novému výzkumnému paradigmatu (naprríklad Balík a Holzer 2006; Gandhi a Lust-Okar 2009; Ptáčník 2012; Morgenbesser 2014), a v neposlední řadě také práce mapující již tak mnohdy nepřehledné bloudění labyrintem hybridních režimů (Drahokoupil 2014).

Jednou z viditelných slabin celé problematiky hybridních režimů, na kterou upozorňovali jak někteří zastánci celého směru, tak i jeho kritici, byla př́tomnost velmi nejasných hranic mezi hybridními režimy a demokracií na straně jedné a hybridními režimy a režimy autoritářskými na straně druhé. Při hledání prŕíčin tohoto stavu se nabízí především dvě možná vysvětlení. To první odkazuje $\mathrm{k}$ povaze celé debaty o hybridních režimech. Vzhledem $\mathrm{k}$ tomu, že se do této diskuze $\mathrm{v}$ jisté době zapojila řada věhlasných autorů, jde o prostředí, ve kterém je kumulován značný akademický kapitál, jež aktéry diskuze přímo vybízí $\mathrm{k}$ formulování nových hypotéz a teoretických konceptů. To ve svém důsledku vedlo řadu autorů nejen $\mathrm{k}$ neustálému zdokonalování teoretického poznání v oblasti výzkumu soudobých forem nedemokratických režimů a k precizování toho, co demokracie je a co nikoliv (Karl a Schmitter 1991), avšak také $\mathrm{k}$ přehlížení jistých nedostatků některých vlastních východisek a související nekritičnosti $\mathrm{k}$ těmto prredpokladům. Ve své podstatě tak celé výzkumné úsilí často připomínalo spíše soutěž o to, kdo dřive príjde s přelomovějším konceptem, než snahu o řešení existujících výzkumných problémů, čímž vlastně na poli hybridních režimů došlo přesně $\mathrm{k}$ tomu, před čím svého času varovali David Collier a Steven Levitsky. ${ }^{4}$ Druhé vysvětlení poté souvisí se samotnou konfigurací výzkumné agendy v oblasti politických režimů, kde stále společně dominují dichotomické a kontinuální prístupy. V rámci nich je totiž vymezení kategorie režimů „v šedé zóně“ velmi problematické.

Za ideální způsob, jak se vymanit ze zmíněné „pasti“ soudobého studia politických režimů, považuje řada autorů (např́iklad Cassani 2014 nebo Gilbert a Mohseni 2011) nekonceptualizovat hybridní režimy ve vztahu k demokracii či

\footnotetext{
${ }^{3}$ Z celé řady klasických textů na téma hybridních režimů jmenujme např́klad proslulý Diamondův „Thinking About Hybrid Regimes“ (2002).

${ }^{4}$ Collier a Levitsky (1997: 449) ve svém dnes již legendárním textu uvádějí: „...pokud výzkum demokracie zdegeneruje $v$ soutěž o to, kdo drrív přijde s přelomovější koncepcí, bude to pro komparativní studie politických režimů znamenat zásadní problém.“
} 
autoritářství, ale jako svébytnou kategorii politických režimů existující naprosto nezávisle na těchto dvou kategoriích. Ve své podstatě se tak prúmo i nepř́ímo odkazují k práci Terry Karl (1995), která na základě svého výzkumu politických režimů ve Střední Americe príšla s touto myšlenkou patrně jako první (Zinecker 2009: 308).

Cílem předloženého textu je přispět do teoretické diskuze o soudobých formách nedemokratických režimů tématem, které bylo dosud opomíjeno, a tím jest komparace soudobých př́stupů upřednostňujících právě trichotomickou klasifikaci (Mainwaring, Brinks a Peréz-Liñán 2001; Wigell 2008; Zinecker 2009; Levitsky a Way 2010 Gilbert a Mohseni 2011). Motivem zamýšlené komparace trichotomických klasifikací hybridních režimů je především snaha odpovědět na otázku, zda a jak se trichotomické klasifikace vyrovnaly se slabými místy dosavadních přístupů $\mathrm{k}$ problematice hybridních režimů. Pokud by totiž neuspěly, znamenalo by to nalomení legitimity celého výzkumného směru, který se ve svém zdůvodnění často odvolává na snahu odstranit tyto nedostatky (např́iklad Wigell 2008; Gilbert a Mohseni 2011; Cassani 2014). S ohledem na stanovenou výzkumnou otázku se komparace trichotomických konceptů soustředí na nejproblematičtější aspekty výzkumu hybridních režimů; tyto aspekty posléze plní úlohu komparačních kritérií. Tím prvním je teoretická stavba jednotlivých konceptů a s ní související odlišení hybridního režimu od demokracie a autoritářství. Druhým kritériem je vymezení volební soutěže: Jak ukáže stručný historický náhled do celé problematiky hybridních režimů, bylo právě nejasné vymezení volební soutěže jedním z největších nedostatků starších konceptů. Posledním kritériem je pak vnitřní dělení této „šedé zóny“ a vymezení případných podkategorií sledovaných konceptů. Zmíněné podkategorie dosud nebyly předmětem hlubší diskuze, což $\mathrm{v}$ praxi vede $\mathrm{k}$ nejistotě při jejich použití, která se projevuje především v tom, že si autoři často nejsou př́liš vědomi charakteristik podkategorií jednotlivých konceptů a považují za kategoricky odlišné koncepty, které se ve skutečnosti spíše překrývají. ${ }^{5}$ Ve snaze o odstranění nejasných hranic mezi hybridními a nehybridními režimy je navíc potřebné, aby byly odstraněny nejasnosti nejen na úrovni samotných konceptů, ale i jejich podkategorií.

Za soudobé trichotomické koncepty hybridních režimů jsou v textu považovány práce Mainwaringa, Brinkse a Peréze-Liñána (2001), Wigella (2008), Zinecker (2009), Levitskyho a Waye (2010) a Gilbert a Mohseniho (2011). Všechny lze považovat za relevantní, protože byly otištěny a diskutovány na stránkách předních odborných časopisů, a přestože se některé netěší takové pozornosti jako jiné, považuji za účelné je pro úplnost uvést všechny. S ohledem

\footnotetext{
${ }^{5}$ Př́́kladem takové situace je poslední kniha Mainwaringa a Peréze-Liñána (2014), ve které autoři považují soutěživé autoritářství Levitskyho a Waye (2010) za „méně demokratickýc př́pad politického režimu než je jejich vlastní semidemokracie, ačkoliv lze na základě definičních kritérií jednotlivých konceptů spíše označit soutěživé autoritářství za jednu z podkategorií zmíněné semidemokracie.
} 
na predikát „soudobé“ tak z výběru vypadla samotná práce Terry Karl, protože je starš́ho data a idea hybridního režimu jako samostatné kategorie politických režimů v ní není přliš rozpracovaná. Dále pak není zařazena práce Friedberta Rüba (2002), která vyšla pouze německy (jako kapitola v monografii) a v mezinárodní odborné komunitě není prŕliš známá. Na Rübovu práci však do jisté míry navazuje Heidrun Zinecker (2009), o jejímž konceptu bude v následujícím textu pojednáno, takže ani tato německá stopa na poli současného výzkumu nedemokratických režimů nebude zcela opomenuta.

\section{Stručný vývoj problematiky hybridních režimů a hlavní body jeho kritiky}

Z teoretického hlediska je možné na hybridní režimy nahlížet dvěma způsoby. Tím prvním je př́stup, který vychází z dichotomického vnímání politických režimů a hybridní režimy považuje za prŕpad neúplné demokracie (Merkel 1999, 2004; O'Donnell 1994; Zakaria 1997), nebo neúplného autoritářství ${ }^{6,7}$ (Ottaway 2003; Schedler 2006). Kořeny tohoto př́stupu jsou pravděpodobně v práci Schmittera a O'Donnella (1986), kteři se zmiňují o existenci nejasných režimů $\mathrm{v}$,šedé zóně“. Schmitter a O'Donnell od sebe posléze odlišují dva typy nejasných režimů: limitovanou demokracií (democradura) a limitované autoritářství (dictablanda) (Zinecker 2009: 304; srov. Balík a Holzer 2006: 7). Druhý př́stup je poté inspirován již zmíněnou prací Terry Karl (1995) a považuje hybridní režimy za plnohodnotnou kategorii politických režimů po boku demokracie a autoritářství (Beichelt 2012: 16-18). Uvedené členění však nesouvisí jen s dichotomickým a trichotomickým vnímáním politických režimů, ale do jisté míry taktéž s paradigmatickým vývojem samotného výzkumu demokratizace $\mathrm{v}$ posledních několika desítkách let. Pokud bychom zmíněnou časovou etapu rozdělili podobně jako Merkel na fázi optimistickou, realistickou a pesimistickou (2010: 18-21), je možné říci, že př́istup založený na vnímání hybridních režimů jako případů nedokonalé demokracie či autoritářství je spojen především s fází optimistickou

\footnotetext{
${ }^{6}$ Mezi př́pady neúplného autoritářství je občas chybně řazen i koncept soutěživého autoritářství Levitskyho a Waye, ačkoliv tito autoři zdůrazňují, že se jedná o specifický druhý politického režimu mezi demokracií a autoritářstvím. Zmíněný stav je pravděpodobně způsobem poměrně matoucím názvem celé kategorie. Je tedy na místě se zamyslet, zda by do budoucna nebylo lepší pro tuto kategorii používat název neliberální hybridní režim, jak navrhují Gilbert a Mohseni (2011: 290).

7 Občas je možné narazit dokonce na více než dva př́stupy. Kupř́lkladu Cassani mluví o pěti prŕstupech (2014: 545-548), avšak jeho kategorie jsou do jisté míry jen ekvivalenty uvedených dvou. Jiní autoři rozlišují tři kategorie hybridních režimů, protože považují případy omezené demokracie a omezeného autoritářství za samostatné kategorie (Schedler 2006:4-5). To však pokládám za zbytečné a souhlasím s Boggardsem (2009: passim), že to jen prohlubuje konceptuální zmatení a že je účelnější obě kategorie sloučit.
} 
a též realistickou. Př́stup vnímající hybridní režimy jako samostatnou kategorii politických režimů je poté možné zařadit především do fáze pesimistické.

Kritiku vůči konceptům hybridních režimů vycházejících z dichotomického vnímání politických režimů je možné spojit do dvou hlavních bodů. Tím prvním byla vysoká míra konceptuálního zmatení, která je s tímto př́stupem spojena. $\mathrm{Z}$ dnešního pohledu je totiž možné říci, že „první generace“ konceptů hybridních režimů, odvozující tuto kategorii od demokracie, byla především snahou o překotné uhašení požáru, ve kterém se ocitl výzkum demokratizace po konci své idealistické fáze - v tu dobu začínalo být stále jasnější, že řada režimů , které tehdejší výzkumníci označili za demokracie, jimi ve skutečnosti není a jedná se v nejlepším př́padě o krystalické případy elektoralismu (Karl 1986). Tím pádem sice první teorie hybridních režimů jako Zakariova neliberálni demokracie (1997) jeden problém řešily, ale zároveň vytvářely řadu dalších. Velmi brzy se totiž začaly objevovat hlasy, které polemizovaly o tom, zda je možné označit kupř́kladu demokracii bez liberální dimenze za demokracii (Mainwaring, Brinks a PerézLiñán 2001: 41), či kolik podobných defektů vlastně může vůbec „demokracie“ unést (Zinecker 2009: 306). Vlna kritiky vůči „první generaci“ konceptů hybridních režimů vyústila v nástup generace druhé, která se rozhodla vydat opačnou cestou. Místo zdůrazňování existence demokratických institucí hybridních režimů se cílem této vlny stalo zdůrazňování jejich autoritářských prvků. Výhodou této cesty bylo vyjasnění hranice mezi demokracií a hybridním režimem, avšak hranice mezi hybridním režimem a autoritářstvím nadále zůstávala nejasná (Gilbert a Mohseni 2011: 274). V praxi je to vidět především v situaci, kdy je často zaměňován Schedlerův koncept elektorálního autoritárství za soutěživé autoritárstuí Levitskyho a Waye. Pokud pomineme výše uvedenou poznámku o tom, že se co do identity jedná o odlišnou kategorii politického režimu, je problém v samotném vnímání voleb. Levitsky a Way totiž do své kategorie počítají jen režimy, ve kterých se koná reálná, leč ne vždy férová soutěž (2002: 55; srov. Dvořáková et al. 2012: 74), avšak Schedlerova kategorie obsahuje i režimy, ve kterých se žádná soutěž nekoná a opozice je vždy předurčena volby prohrát (2006: 14).

Př́lišné soustředění na analýzu voleb je zároveň druhým bodem kritiky, která byla vůči problematice hybridních režimů vznesena. Její jádro tkví v pochybnostech o tom, že je možné uspokojivě klasifikovat celou škálu politických režimů jen na základě analýzy jedněch voleb (Balík a Holzer 2006: 18). Kritici tohoto postupu správně poukazují, že toto klasifikační kritérium je nedostatečné a jeho zastánci v rámci paradigmatu hybridních režimů se nesnaží možná rizika dostatečně reflektovat. I kdybychom totiž přistoupili na to, že opravdu můžeme uspokojivě rozdělit nedemokratické režimy pouze podle míry (ne)svobody voleb v nich konaných, jak tvrdí v již uvedeném textu Diamond (2002), vzbuzují nabízená kritéria přinejmenším pochyby. Ani u dalších autorů té doby, snažících se o podobné dělení, není situace o mnoho lepší (naprríklad 
v článku Levitskyho a Waye z roku 2002). Kritika klasifikace nedemokratických režimů pouze na základě voleb má ještě jeden směr, který ve své práci taktéž nastínili Balík a Holzer (2006), avšak v jeho rozpracování se dostal nejdále australský politolog Lee Morgenbesser (2014). Jde konkrétně o otázku, zda je možné hodnotit volby v nedemokratickém režimu na základě funkce, kterou mají v režimu demokratickém. Jak totiž ukazuje celá řada autorů věnujících se současným autoritářským režimům (např́klad Ganhdi a Lust-Okar 2009), plní $\mathrm{v}$ těchto režimech volby povětšinou jiné funkce, a v takovém př́ípadě je otázkou, proč by měly být právě volby $\mathrm{v}$ hybridních režimech analyzovány pouze optikou voleb v demokratických režimech (více o volbách v autoritářství viz např. Miller 2012).

Nejstarší z textů, kterému se tento prríspěvek podrobněji věnuje, spatřil světlo světa v roce 2001 a byl v něm rozveden koncept semidemokracie Mainwaringa, Brinkse a Peréze-Liñána. Autoři se zde snažili reagovat na řadu problémů spojených s klasifikací politických režimů. Mimo již zmíněných to byla pochybná věrohodnost většiny tehdejších klasifikací a spor o to, zda je lepší klasifikovat politické režimy pomocí kontinuální škály nebo dichotomické klasifikace. Zmíněnou diskuzi označili Mainwaring a jeho kolegové za falešnou a nejlepší řešení všech zmíněných problémů viděli v zavedení trichotomické klasifikace politických režimů (Mainwaring et al. 2001: 37). Jak totiž poznamenali, problém není $\mathrm{v}$ tom, jestli rozlišujeme mezi dvěma kategoriemi na základě kontinuální nebo kategorické klasifikace, ale $\mathrm{v}$ tom, že ani jeden z těch způsobů není schopný uspokojivě klasifikovat režimy v šedé zóně (Mainwaring, Brinks a Peréz-Liñán 2007: 138-142). Jejich trichotomická klasifikace tedy obsahuje kromě demokracie a autoritářství ještě třetí kategorii, kterou nazvali semidemokracie.

Ani koncept semidemokracie se však neobešel bez kritických ohlasů. Autorem patrně nejucelenější kritiky celého konceptu je Wigell (2008), kterému vadilo, že koncept neumožňuje zachytit větší variabilitu v kategorii demokracie především $\mathrm{v}$ souvislosti s problematikou rezervovaných domén a různých forem populismu, které jsou v celém konceptu přehlíženy (2008: 233). Zde je však třeba poznamenat, že sám Peréz-Liñán uznává, že jejich kritéria pro definování demokracie, nejsou schopna „plně obsáhnout komplexnost demokratického života“ (Altman a Peréz-Liñán 2002: 95) a opomijí již zmíněné rezervované domény ve významu, jaký tomuto termínu dává kupŕíkladu Valenzuela (1990). Wigell se neomezil pouze na kritiku práce Mainwaringa, Brinkse a Peréze-Liñána. Podobně jako dalším autorům mu vadilo přeceňování analýzy voleb při klasifikaci nedemokratických režimů obecně a především slavná Diamondova studie (2002). Wigell nezůstal jen u kritiky existujícího stavu a předložil vlastní koncept politických režimů. Ve snaze vyvarovat se problémů tehdejšího výzkumu navrhl dvojdimenzionální klasifikaci, která si mimo voleb všímá konstitučních prvků daného systému (Wigell 2008: 231-236). 
Hlavní body zmíněné kritiky, tedy především problematiku nejasné hranice mezi demokracií a hybridním režimem, je možné identifikovat taktéž v práci od Heidrun Zinecker (2009). Specifikem jejího přístupu poté je, že ačkoliv svůj teoretický koncept publikovala v roce 2009, ve skutečnosti v něm pouze reagovala na výtky vǔči dichotomickým klasifikacím hybridních režimů (především těm, které považují hybridní režimy za př́pady omezené demokracie). Naprosto tak opominula trichotomické klasifikace vzniklé před datem publikování jejího textu. Jistá izolovanost její práce ve vztahu k probíhajícím teoretickým diskuzím je poté dána taktéž tím, že je silně ovlivněna příspěvky, které vycházejí z německého prostř̌edí. Inovací jejîho př́istupu je poté snaha o začlenění občanské společnosti do konceptu politických režimů. Občanskou společnost chápe nenormativně, může tedy být jak demokratická, tak nedemokratická. Zinecker je přesvědčena, že její podoba je pro charakter režimu rozhodující, protože demokratické instituce nemohou fungovat, pokud je občanská společnost neuznává (Zinecker 2009: 310).

Koncept hybridních režimů Levitskyho a Waye si za pár let své existence vyrobil výsadní postavení nejen na poli bádání o hybridních režimech, ale svým způsobem i ve výzkumu současných forem nedemokratických režimů obecně. Jejich známá publikace Competitive Authoritarianism: Hybrid Regimes after the Cold War (Levitsky a Way 2010) vzbudila v soudobé komparativní politologii tak velký ohlas, že dokonce někteří autoři označili Levitskyho a Waye za Stepana a Linze své doby (Raun 2013) a pro jiné se stalo jejich pojetí soutěživého autoritářství takřka synonymem hybridních režimů v současném světě (Ekman 2009). Pro úplnost je třeba uvést, že základem jejich přelomové práce byla řada starších textů na téma hybridních režimů a jejich stability v současném světě. Pro kontext méhjo př́spěvku stojí za zmínku především článek „The Rise of Competitive Authoritarianism“ uveřejněný roku 2002 v Journal of Democracy, ve kterém poprvé seznámili odbornou veřejnost se svým pojetím hybridních režimů a př́edevším $\mathrm{s}$ „vlajkovou lodi““ svého konceptu hybridních režimů v podobě soutěživého autoritárství. Motivem $\mathrm{k}$ práci byla pro Levitskyho a Waye především podoba tehdejšího světa, která dle jejich názoru nebyla adekvátně reflektována v odborné literatuře - především tedy existence specifických režimů $\mathrm{v}$ „šedé zóně“, které kombinují demokratické a nedemokratické prvky.

Gilbert a Mohseni publikují svou práci až v roce 2011, takže měli dost času seznámit se z probíhající teoretickou diskuzí. Jejich snahou bylo představit koncept hybridních režimů jakožto nezávislé kategorie politických režimů, který bude dobře použitelný pro kvantitativní analýzu politických režimů (Gilbert a Mohseni 2011: passim). Z předchozích autorů na poli hybridních režimů se hlásí především k práci Levitskyho a Waye (2010), protože jsou silně ovlivněni jejich pojetím nerovného pole. Ostatní práce autorů pracujících s trichotomickou klasifikací mimo Wigella nezmiňují. Na jejich práci je zajímavé, že se hlásí k odkazu Giovanni Sartoriho (1976) a Juana Linze (1970), a zároveň je celý 
koncept vytvořen s ohledem na nejnovější metodologicko-konceptuální poznatky Gerarda Muncka (2001, 2006) a Garryho Goertze (2006).

\section{Vymezení demokracie a autoritářství}

Dobrý koncept v sociálních vědách by podle Garyho Goertze neměl obsahovat jen své pozitivní vymezení, ale i vymezení negativní. Např́klad pokud má koncept demokracie 3 podmínky, které musí být naplněny, aby bylo možné sledovaný režim označit za demokracii (pozitivní vymezení), je třeba taktéž definovat, jak vypadá negativní vymezení našeho konceptu v př́padě, že námi sledovaný režim nenaplňuje žádnou z požadovaných podmínek. V klasické dichotomické klasifikaci politických režimů by tak ideálně měla být na jedné straně demokracie (při naplnění všech definičních podmínek) a na straně druhé definovaná forma nedemokracie (nejčastěji autoritářství), aby bylo možné koncept úspěšně falsifikovat (Goertz 2006: 30-34). Vzhledem k tomu, že pro současné klasifikace politických režimů je naprosto stěžejní vymezení demokracie, měla by v logice tohoto pravidla vypadat trichotomická klasifikace politických režimů ideálně tak, že na jednom konci spektra se bude nacházet demokracie (pozitivní vymezení konceptu při naplněný všech jeho definičních podmínek), na druhém autoritářství (negativní vymezení demokracie, ve kterém není naplněná žádná definiční podmínka) a uprostřed bude hybridní režim, který naplňuje jen některé podmínky pozitivního vymezení demokracie. Při nedodržení tohoto pravidla je totiž jen velmi těžké jasně odlišit hybridní režim od demokracie a autoritářství, což je, jak bylo avizováno výše, jedna z častých výtek vůči celé řadě starších konceptů hybridních režimů.

Koncept semidemokracie je postaven na minimální procedurální definici demokracie. ${ }^{8,9} \mathrm{Z}$ toho důvodu jsou pro klasifikaci politických režimů určující čtyři kritéria, konkrétně svobodné a soutěživé volby, všeobecné volební právo, garance občanských a politických práv a absence poručnického vlivu (Mainwaring, Brinks a Peréz-Liñán 2007: 124). Demokracie je poté režimem, který naplňuje všechna čtyři kritéria. $\mathrm{Na}$ základě míry porušení sledovaných kritérií potom režim klasifikovali bud' jako semidemokracii, nebo jako autoritářství. Zde je třeba konstatovat, že pro zařazení mezi semidemokracii musí zkoumaný režim vždy splňovat kritérium svobodných a férových voleb. Pokud se totiž ve zkoumaném režimu nekonají svobodné a soutěživé volby, jedná se automaticky o autoritářský režim a není třeba věnovat pozornost klasifikaci dalších kritérií (Mainwaring,

\footnotetext{
8 Řada autorů dávala před „procedurální definicí“ navazující na práci Dahla přednost subminimální definici vycházející z práce Josepha Schumpetera. Subminimální definice byla použita např́klad ve významné práci Democracy and Development: Political Institutions and Well-Being in the World, 1950-1990, za kterou stál kolektiv autorů v čele s Adamem Przeworskim (Przeworski et. al. 2000).

${ }^{9} \mathrm{~V}$ textu je volen doslovný překlad termínu užitého autory. V českém prostředí je možné často narazit taktéž na výraz rozšířené procedurální minimum (Drahokoupil 2014: 20).
} 
Brinks a Peréz-Liñán 2001: 48). Vzhledem $\mathrm{k}$ tomu, že $\mathrm{v}$ intencích tohoto konceptu politických režimů je demokracie odlišena od hybridního režimu (semidemokracie) a autoritářství na základě míry porušení daných kritérií, je zde ponechán velký prostor pro arbitrární rozhodnutí. To je dále umocněno faktem, že režim označený za autoritářský může teoreticky selhávat jen $\mathrm{v}$ jednom z klasifikačních kritérii (ibid.: 44-48). Záměrně říkám teoreticky, protože zmíněná čtyři kritéria jsou dosti provázaná a všechny se svým způsobem odkazují k již zmíněné podmínce svobodných a férových voleb (vrátíme se $\mathrm{k}$ tomu $\mathrm{v}$ další sekci). Arbitrárnost svého konceptu si uvědomují i sami autoři, avšak dodávají, že klasifikace politických režimů „vždy obnáší nějaké subjektivní soudy“(ibid.: 37), a proto usilují především o co největší transparentnost svých voleb.

Wigell (2008) se oproti autorům konceptu semidemokracie snaží o mnohem přesnější vymezení. $V$ jeho pojetí existuje na jedné straně minimální demokracie, která naplňuje čtyři základní podmínky volební dimenze a čtyři základní podmínky konstituční dimenze. Opakem demokracie je ve Wigellově modelu autoritárství, které nesplňuje žádnou $z$ těchto osmi podmínek. Mimo těchto dvou typů rozeznává Wigell ještě volební autokracii a konstituční oligarchii, tedy dva druhy hybridního režimu. Volebni autokracie je režimem, který splňuje čtyři základní podmínky volební dimenze, ale absentují u něj všechny, anebo alespoň některé ze základních podmínek konstituční dimenze. Situace konstitučni oligarchie je poté přesně opačná. Jde tedy o režim, který naplňuje základní podmínky konstituční dimenze, ale je nedostatečný v dimenzi volební (Wigell 2008: 242-245). Specifikem Wigellova pojetí je, že umožňuje ještě hlubší rozlišení v rámci samotné kategorie „demokracie“, a to s využitím čtyř doplňujících podmínek v každé ze dvou zmíněných dimenzí. Logika je poté stejná. Režim, který naplňuje jen osm základních podmínek, je limitovanou demokracií. Jeho opakem jest liberální demokracie, která naplňuje všech 8 doplňujících podmínek. Mimo toho definuje ještě volební demokracii a konstitučni demokracii, přesně podle pravidel, která byla zmíněna v prípadě volební autokracie a konstituční oligarchie (Wigell 2008: 245-247).

Zinecker pracuje s konceptem politických režimů, který sestává ze čtyruiatřiceti definičních podmínek rozdělených do pěti oblastí (civilní vláda, polyarchie, vláda práva, „civilizovanost“ a ekonomická inkluze). Vzhledem $\mathrm{k}$ autorčině snaze začlenit do svého konceptu rozměr občanské společnosti a další prvky, které většina konvenčních teorií demokracie opomíjí (jako ekonomickou inkluzi nebo schopnost režimu čelit organizovanému zločinu), je její koncept velmi podrobný a komplikovaný. Větším problémem však je, že jednotlivé podmínky nemají stejnou váhu, a tak ani demokracie nemusí naplňovat všech čtyríiatřicet podmínek. Autoritářský režim poté $\mathrm{v}$ jejím pojetí taktéž neselhává ve všech těchto kategoriích, ale jde o režim, který bud’ nemá civilní vládu, nebo se $\mathrm{v}$ něm stručně řečeno nekoná volební soutěž. Hybridní je pro Zinecker režim, který nesplňuje podmínky režimu autoritářského a nenaplňuje klíčová kritéria každé $z$ oněch pěti oblastí. Minimálně hranice mezi hybridním režimem a demokracií je tak velmi 
nejasně formulována (Zinecker 2009: 311-313). Pocit nejasnosti se autorce nedaří odstranit ani při následné aplikaci celého konceptu v praxi. Navíc, zatímco $\mathrm{v}$ teoretické části mluví o tom, že podmínky jsou bud’ naplněny, nebo nenaplněny, v prŕípadové studii Kolumbie u některých podmínek autorce najednou stačí, když jsou naplněny jen částečně (Zinecker 2009: 313-324). Celý teoretický koncept tak $\mathrm{v}$ řadě momentů působí ještě arbitrárněji než práce Mainwaringa, Brinkse a Peréze-Liñána, avšak oproti zmíněným autorům si toho není Zinecker vědoma a nesnaží se nedostatky svého konceptu reflektovat.

Podobně jako Manwaring et al. vymezuji i Levitsky a Way demokracii na základě Dahlova procedurálního minima. Jedinou změnou je, že zmíněnou Dahlovu definici demokracie považují oproti jiným autorům za výrazně Schumpeterovskou ${ }^{10}$ a obohacují ji o pátou dimenzi, kterou představuje úroveň nerovnosti hracího pole, $v$ němž zápolí vládnoucí strana s opozicí. ${ }^{11}$ Tato dimenze je v řadě teorií demokracie prítomna, ale není jí věnován dostatek pozornosti. Proto dochází k tomu, že je při klasifikaci politického režimu sice běžně sledována míra nerovnosti hracího pole, ale většinou jen v době konání voleb a v rámci jiných dimenzí. ${ }^{12}$ Podle Levitskyho a Waye je však třeba věnovat pozornost těmto proměnným po celé volební období a samostatně, protože jinak existuje velká šance, že nám uniknou klíčové charakteristiky zkoumaného režimu (Levitsky a Way 2010: 6-8). Poněkud nečekaně však pro samotnou operacionalizaci navrhují schéma, které začíná od autoritářství. To je v jejich pojetí režimem, v němž se nekonají na národní úrovni volby, kterých se účastní více politických stran, nebo tyto volby provází masivní falšování výsledků, či je hlavním opozičním silám znemožněno se voleb účastnit. Pokud se volby na národní úrovni konají, ale hrací pole je nerovné, jde o bybridní režim (přičemž vymezují celkem čtyři jeho podkategorie, o kterých ještě bude řeč). Konečně pokud se konají volby, soutěž není omezena a nevolené složky nezasahují do politického rozhodování, jedná se o demokracii (Levitsky a Way 2010: 365-368).

Gilbert a Mohseni staví svůj koncept také na trojdimenzionální klasifikaci. Mimo existence a kvality volební soutěže si při klasifikaci politického režimu všímají, zda mají na tvorbu politiky zkoumaného státu vliv nevolení aktéři, tedy poručnické organizace (Gilbert a Mohseni 2011: 280-286). Podobně jako Valenzuela (1990) nebo Karl a Schmitter (1991) se totiž domnívají, že je pro demokracii nezbytně nutné, aby politická moc byla $\mathrm{v}$ rukou těch, kteří $\mathrm{k}$ tomu získali mandát ve volbách (Schmitter a Karl 1991: 81). Své tři definiční znaky, tedy existenci volební soutěže, míru soutěživosti a vliv nevolených aktérů, chápou jako

10 Tím mají na mysli, že ačkoliv se definice označuje za procedurální, je ve své převažující interpretaci často orientovaná především na volby (Levitsky a Way 2010: 6).

11 Levitsky a Way uznávají, že ,jistý stupeň zvýhodnění obhájce úřadu [incumbent] existuje i ve všech demokratických režimech. V demokratických režimech však toto znevýhodnění zásadně neomezuje manévrovací prostor opozice ve volebním kláni““ (2010: 6).

${ }^{12}$ Konkrétně mají na mysli dimenze volební a občanských svobod (Levitsky a Way 2010: 6). 
tř́ dimenze nezbytně nutné pro klasifikaci politického režimu (Gilbert a Mohseni 2011: 284). Demokracie je definovaná jako režim, ve kterém existuje volební soutěž, míra soutěživosti je vysoká a nevolení aktérí nemají vliv na politiku. Přirozeným opakem je režim autoritářský, ve kterém jsou hodnoty všech tř́ proměnných opačné. Hybridni režim je poté charakteristický tím, že v něm existuje volební soutěž, avšak míra soutěživosti je nižší než v demokracii. Nevolení aktéři potom na politiku hybridního režimu mohou, ale nemusejí mít vliv.

\section{Problematika volební soutěže v komparovaných konceptech}

Mainwaring, Brinks a Peréz-Liñán považují volby za svobodné a férové, pokud míra volebních podvodů není tak vysoká, aby znemožňovala opozici zvítězit, a míra represe ze strany obhájce úřadu (tzv. inkumbenta) či nevolených složek státní moci nesmí znemožnit její účast (Mainwaring, Brinks a Peréz-Liñán 2001: 46-47; Mainwaring, Brinks a Peréz-Liñán 2007: 138). Krom již komentované arbitrárnosti takového vymezení je problémem taktéž fakt, že i ostatní kritéria režimní klasifikace, které autoři vymezují, se až př́liš orientují na zmíněný volební proces. Uved'me jeden prúklad za všechny. Částečné porušení třetího kritéria, tj. „občanských svobod“, nastane, když je zakázána jedna z hlavních opozičních stran nebo některý $z$ hlavních opozičních kandidátů (Mainwaring, Brinks a Peréz-Liñán 2001: 47). Jak poznat, který zákaz významné opoziční strany či kandidáta je ještě „únosnýc a který již nikoliv? Je evidentní, že představený klasifikační rámec je metodologicky stále velmi problematický a navzdory čtyřem deklarovaným kritériím vlastně je orientován výhradně na volební proces, se všemi zmíněnými neduhy tohoto metodologického řešení.

Wigellovo vymezení podmínek, za kterých existuje volební soutěž, je poměrně nejasné a souvisí s tím, jak autor vnímá jednotlivé kategorie své typologie. Ačkoliv to na první pohled nemusí být patrné, nerozděluje režimy na ty, ve kterých existuje volební soutěž, a ty, kde absentuje, nýbrž na režimy, ve kterých se konají nějaké volby, a režimy, kde se volby nekonají. Do jím navržené kategorie volebni autokracie tak podle něj patří jak soutěživé autoritářství, tak volební autoritářství či hegemonické autoritářství, ve kterém se konají volby. Do kategorie konstitučni oligarchie poté řadí režimy bez voleb nebo konstituční oligarchie Evropy na konci 19. století (2008: 244-245). Nejasnosti vymezení je však alespoň částečně kompenzována dvoudimenzionálností jeho klasifikace.

O mnoho lepší řešení problému neprrináší ani Zinecker. V jejím konceptu hybridních režimů jsou totiž volby svobodné a férové, pokud jsou prosty násilí a manipulace a všichni dospělí obyvatelé smí volit a kandidovat (Zinecker 2009: 311). Sama poté v prrípadové studii Kolumbie stanovuje „míru volební svobody“ poměrně arbitrárně (Zinecker 2009: 313-324). Na obhajobu autorky je třeba říci, že se při své operacionalizaci politických režimů neomezuje jen na volby nebo 
proměnné, které s nimi př́mo souvisejí, a tak je tento nedostatek částečně kompenzován.

Pro Levitskyho a Waye je znakem reálné volební soutěže skutečnost, že se voleb na národní úrovni účastní více politických stran a o vítězi není dopředu rozhodnuto (Levitsky a Way 2010: passim). Vycházejí tak z předpokladu, že opozice je sice znevýhodněna, ale stále může ve volbách uspět. Jejich slovy je poté volební klání „jako fotbalový zápas, kde má každý tým jiné rozměry branky a k tomu jeden tým tvoři jedenáct hráčů a rozhodčí a druhý si musí vystačit v pěti nebo šesti“ (Castañeda 1996: 131 srov. Levitsky a Loxton 2013: 108). Tím, že zároveň navrhují sledovat po celé předcházející volební období úroveň nerovnosti hracího pole, na kterém zápolí vládnoucí strana s opozicí, se jim daři částečně reagovat na předcházející kritiku - především pak na tu její část, která vycházela z nemožnosti zachytit dobře charakter politického režimu jen na základě analýzy jedněch voleb. Do jisté míry dokonce mírí i za doporučení srovnat dvoje po sobě jdoucí volby ve zkoumaném státě (viz Balík a Holzer 2006: 18). I takto zvolené rozlišení je problematické, avšak autoři se snaží své metodologické řešení podpořit velmi propracovanou operacionalizací a podrobným vysvětlením konceptu nerovného herního pole. Pro řadu kritiků tak bude jejich př́stup stále nedostatečný, avšak je na něm vidět kvalitativní posun a snaha reflektovat problémy, které sebou klasifikace opírající se především o volby přináší.

Gilbert a Mohseni pod vlivem práce Levitskyho a Waye (2002, 2010) a Sartoriho (1976) provádějí redefinici termínu soutěživé volby a místo počtu stran, které se účastní voleb, sledují, zda se na základě voleb „rozděluje politická moc mezi rozličné politické skupiny“ (Gilbert a Mohseni 2011: 278). Př́tomnost skutečné soutěže totiž odlišuje hybridní režimy od režimů autoritářských, které tento znak postrádají. Mírou soutěživosti voleb je poté možné naopak jasně odlišit hybridní režimy od demokracií. Dle Gilbert a Mohseniho ,jsou totiž demokracie soutěživé režimy se spravedlivou soutěží a autoritářské režimy nesoutěživé režimy s nespravedlivou soutěží. Pro hybridní režimy je oproti tomu charakteristická právě kombinace soutěživých voleb a nespravedlivé soutěže" (Gilbert a Mohseni, 2011: 280). Nedostatkem jejich pojetí však je, že ačkoliv se v teoretické rovině hlásí ke konceptu nerovného herního pole Levitskyho a Waye, není to v praktické rovině př́liš vidět. Dle teoretické konstrukce $\mathrm{v}$ pozadí celého prŕistupu by totiž zmíněná proměnná měla tvořit druhou dimenzi jejich klasifikace. K určení zmíněné dimenze potom doporučují bud' proměnnou občanských svobod (Civil Liberties) podle hodnocení organizace Freedom House, nebo proměnnou POLCOMP (political competition) z datasetu Polity IV. Problémem však je, že se obě proměnné chovají naprosto odlišně. Proměnná občanských svobod svou povahou poměrně dobře odpovídá pojetí, které navrhují Levitsky a Way (2010: 5-6). Proměnná POLCOMP (Marschall et al. 2012) ovšem kvůli své konstrukci představuje přesný opak a hodí se spíše k určení volební soutěživosti ve smyslu, jaký Levitsky a Way kritizovali. 


\section{Rozdělení šedé zóny}

Rozlišení v rámci samotné „šedé zóny“ se u komparovaných konceptů liší především ve dvou aspektech. Tím prvním je otázka, zda autoři opravdu pracují s celou škálou režimů mezi demokracií a autoritárstvím, nebo jen s režimy, které se vyznačují existencí volební soutěže. Snahu o první řešení nacházíme pouze u Wigella, protože ostatní autoři považují volební soutěž za definiční znak hybridního režimu. Režimy, ve kterých neexistuje volební soutěž, většina autorů rovnou řadí do kategorie režimů autoritářských. Tím stojí v opozici vůči těm, kdož se domnívají, že existují i hybridní režimy, ve kterých jsou volby nesoutěživé jako již zmíněný Schedler (2006) nebo Ottaway (2003).

Ve druhém aspektu poté jde o to, zdali trichotomický koncept hybridních režimů počíá s podkategoriemi, nebo má pouze jednu velkou kategorii pro všechny hybridní režimy. Cestou jedné kategorie se ve své práci vydala Zinecker a autoři konceptu semidemokracie. Svým způsobem tak vlastně dělají z hybridního režimu reziduální kategorii, pokrývající všechny režimy mezi demokracií a autoritářstvím, ve kterých se koná volební soutěž. To sebou přrirozeně nese riziko v podobě vysoké heterogenity ${ }^{13}$ celé kategorie, což může v řadě výzkumů snižovat její analytickou užitečnost, protože bude obsahovat př́liš odlišné režimy (Cassani 2014).

Ostatní autoři svou kategorii hybridních režimů dále člení. U Wigella jsou to podkategorie volební autokracie a konstituční oligarchie. Jelikož podle něj do kategorie volební autokracie patři vedle soutěživého autoritářství i autoritářství volební a hegemonické (Wigell 2008: 244-245), jedná se vlastně o teoreticky ještě širší kategorii, než jakou je kategorie semidemokracie. Levitsky a Way počítají rovnou se čtyřmi podkategoriemi hybridních režimů. Mimo soutěživého autoritářství je to potom exkluzivini republika $a^{14}$, poručnický režim ${ }^{15}$ a restriketivní demokracie $^{16}$. Konečně Gilbertová a Mohseni rozdělují hybridní režimy na tři

${ }^{13}$ Kritika konceptu semidemokracie z důvodu jeho př́lišné extenze není ničím novým; viz např. Dvořáková et al. (2012).

14 Exkluzivní republika je hybridní režim, který má soutěživé volby, avšak některé skupiny obyvatelstva nemohou vykonávat svá politická práva. Př́kladem takového režimu měli být Estonsko a Litva na počátku 90. let (Levitsky a Way 2010: 14).

15 Jde o režim, ve kterém existují soutěživé volby, nicméně zvolená vláda je omezována ze strany nevolených autorit. Př́ikladem takového režimu je např́iklad současný Irán nebo některé země Střední Ameriky v 90. letech (Levitsky a Way 2010: 14).

16 Restriktivní demokracie je podle Levitskyho a Waye hybridním režimem, ve kterém jsou sice soutěživé volby, ale některé významné politické strany jsou zakázány. V této souvislosti mluví o Turecku v 90. letech a Argentině mezi lety 1956-1966 (2010:14). 
podkategorie, a to neliberální bybridní režim ${ }^{17}$, poručnický režim ${ }^{18}$ a poručnické neliberální režim ${ }^{19}$.

Ačkoliv není možné definitivně určit adekvátní počet podkategorií, je vhodné se v souvislosti se dvěma posledními (a co do počtu nejbohatšími) koncepty u jejich vymezení pozastavit. Jak již ukázala řada autorů, kteří se věnovali tvorbě konceptů v politologii, představuje př́liš široká kategorie jen polovinu problému. Druhou polovinou je pochopitelně natolik restriktivní kategorie, že odpovídá pouze několika př́padům či jen jednomu (Sartori 1970; Collier a Mahon 1993; Collier a Levitsky 1997; Goertz 2006). Pokud se na okamžik vrátíme k práci Terry Karl (1995), vidíme, že na velmi obecném základu uvažuje o dvou podkategoriích hybridního režimu. Ty bychom s použitím pozdější terminologie mohli označit za režim poručnický a neliberální. Taková řešení je z dnešního hlediska pochopitelné, protože vycházela ze své zkušenosti s areálem Střední Ameriky, a tudíž jí chyběla zkušenost $\mathrm{s}$ režimem, jenž by systematicky zamezoval nějaké skupině obyvatel ve výkonu politických práv. ${ }^{20}$ Konkrétně u podkategorie exkluzivní republiky samozřejmě vyvstává otázka, nakolik je relevantní v ostatních areálech. V této souvislosti je třeba konstatovat, že důvod, proč tuto kategorii nemají ve svém konceptu obsaženou Gilbert a Mohseni, souvisí s jejich přesvědčením, že pro klasifikaci politického režimu naprosto stačí jejich tři dimenze (2011: passim). Účelnost „,neliberální kategorie“ je v současném světě nesporná. Je poměrně jedno, zda ji budeme nazývat soutěživým autoritářstvím nebo neliberálním hybridním režimem. Podstatné je, že se jedná o nejčastější, a jak dokládá řada výzkumů (např́klad Bunce a Wolchick 2010), taktéž vnitřně nejrozmanitější kategorii hybridních režimů. ${ }^{21}$

Nejproblematičtější podkategorií jsou bezesporu režimy poručnické. ${ }^{22}$ V souvislosti s poručnickými režimy si někteří kladou otázku, zda je možné takový

\footnotetext{
${ }^{17}$ Režim bez poručnického vlivu, ve kterém existují soutěživé volby, avšak jejich soutěživost je omezena zvýhodněním obhájce mandátu (Gilbert a Mohseni 2011: 290). Podle autorů (tamtéž) se jedná o kategorii, která odpovídá soutěživému autoritářství Levitskyho a Waye.

18 Režim, ve kterém je moc vlády omezována zásahy poručnických institucí (Gilbert a Mohseni 2011: 292).

${ }^{19}$ Režim, ve kterém je moc zvolené vlády omezována zásahy poručnických institucí, ale zároveň je vliv poručnických institucí patrný i na snížené úrovni občanských práv (Gilbert a Mohseni 2011: 292).

20 Pokud se podíváme na klasifikaci režimů v Latinské Americe, kterou sestavili Mainwaring, Brinks a Peréz-Liñán (2007: 167-160), vidíme, že tam od roku 1900 neexistoval žádný režim, který by se dal v tomto ohledu označit za př́ípad exkluzivní republiky.

21 Tato vnitřní rozmanitost je často terčem kritiky, protože někteří autoři polemizují o tom, zda je vhodné mít kategorii, kam lze zařadit režimy s velmi odlišnou mírou represe a znevýhodnění opozice - kupř́kladu ve své době jen těžko kvalitativně souměřitelné prŕpady jako Slovensko za Mečiara a Zimbabwe za Mugabeho (Levitsky a Way 2010). Podle Bunce a Wolchick je však zmíněná rozmanitost do jisté míry symptomatická a není na škodu (2010).

22 Mezi ty počítám jak poručnický a neliberální poručnický režim Gilbertové a Mohseniho, tak poručnický a semirestriktivní režim Levitskyho a Waye.
} 
režim označit za hybridní. Kupř́kladu Wahman, Teorell a Hadenius klasifikují tyto režimy jako vojenské nebo monarchistické, protože pokud podle nich kupř́íladu armáda tajně vládne, je to klíčovější charakteristika režimu, než to, že má soutěživé volby (Wahman, Teorell a Hadenius 2013: 28). Kritici tak vlastně naráží na stejný problém určení míry, který již byl diskutován v souvislosti s volbami v hybridních režimech. Ačkoliv jsem si vědom, že je d’ábel ukryt v detailu, domnívám se, že je zde situace pro trichotomické klasifikace hybridních režimů př́znivější. Podle mého názoru je totiž zásadní rozdíl mezi autoritářským režimem pod vedením armády a poručnickým hybridním režimem, ve kterém sice kupř́kladu armáda má jistou politickou moc, avšak výrazně menší. Využijeme-li definice semidemokracie podle Mainwaringa, Brinkse a Pereze-Liñána (2001: 47), jde tedy o rozdíl tedy prŕpadem, kde ,armáda otevřeně dominuje hlavním politickým oblastem“ a stavem kdy je „schopna vetovat rozhodnutí v některých politických oblastech“. Otázkou samozřejmě zůstává, které politické oblasti označit za klíčové a které nikoliv. Zde záleží na rozhodnutí výzkumníka a použité definici poručnického vlivu, protože existuje rozdíl mezi „evropskou“ tradicí na jedné straně a koncepty poručnického vlivu, které vznikly při výzkumech latinskoamerických zemí, na straně druhé. Podle „evropské“ tradice, kterou můžeme identifikovat např́klad v práci Stepana (1988), je důležité, aby byla armáda naprosto podřízena civilní vládě. Práce autorů specializujících se na areál Latinské Ameriky potom tolerují jistou míru autonomie poručnických sil a klíčové pro ně naopak je, aby armáda neovládala civilní vládu. Př́klad takové tradice je možné najít mj. v práci Fitche (1998) nebo Ruhla (2005).

V souvislosti s podkategorií poručnických režimů je nutné zmínit pravděpodobně největší nedostatek konceptu Gilbert a Mohseniho. Ti totiž ve své práci deklarují, že podobně jako Merkel (1999, 2004) sledují nejen vliv poručnických institucí, ale i př́tomnost tzv. rezervovaných domén. ${ }^{23,24}$ Ve svém článku však neposkytují bližší informace o operacionalizaci ani použitých datech, což je přinejmenším netransparentní. V dizertační práci poté Gilbert (2012: 55-56) pro vymezení poručnického vlivu vychází z Fitchovy typologie (Fitch 1998: 42; srov. Ruhl 2005: 73-75). Problémem však je, že dochází ke stejným

${ }^{23}$ Rezervovanou doménou je myšlena oblasti politiky bez vlivu volených zástupců, na kterou mají naopak vliv poručnické síly. Valenzuela za př́klad rezervované domény považuje centrální banku v Chile po pádu Pinochetova režimu. Ta totiž byla stranou vlivu politiků, ale pod pŕímým vlivem bývalých př́slušníků junty, protože významně rozhodovali o složení jejího vedení (Valenzuela 1990).

${ }^{24}$ Vedle termínu rezervovaná doména lze ještě narazit na termín autoritářská enkláva a autoritářská rezidua. Někteří autoři potom považují zmíněné termíny ve stejném významu (např́íklad Garretón 1989). Valenzuela s tímto postupem nesouhlasí, ,protože enklávy jsou oddělené entity uvnitř, bez napojení na ostatní. Což neodpovídá skutečné povaze, jelikož se v praxi jedná o oblasti, které mají napojení na ostatní a jsou často i centrem politických problémů. Podobně nevhodné je označit rezervovanou doménu za pouhé reziduum, protože rezidua jsou zbytkové prvky neovlivňující okolí, což opět není př́pad rezervované domény“ (Valenzuela 1990: 11; srov. Garretón 1989). 
výsledkům jako v již zmíněném článku, ačkoliv je poměrně evidentní, že Fitchova typologie nedovede prrítomnost rezervovaných domén měřit. ${ }^{25}$

V tomto kontextu je zajímavé, že Wigell sice ve své práci s existencí rezervovaných domén počítá, avšak nepovažuje je za znak nedemokratického režimu. V jeho pojetí se jedná o pouhý defekt demokracie (Wigell 2008: 240-242). Nutno poznamenat, že zmíněný nedostatek se konceptu Levitskyho a Waye netýká pravděpodobně jen proto, že ve své práci blíže nespecifikují, co si pod pojmem poručnický vliv představují (2010: 14, 365-370). Ve svém důsledku je to pak především důvod k povzdechnutí, protože aktuální stav opět jen prohlubuje nejistotu ohledně hranice mezi hybridními a nehybridními režimy.

\section{Trichotomické klasifikace: řešení problému paradigmatu hybridních režimů?}

Komparace vybraných aspektů trichotomických klasifikací hybridních režimů poměrně dobře ukazuje, že i přes deklarovaný sdílený cíl, tedy snahu o vymezení hybridních režimů jako svébytné kategorie politických režimů, se jedná o poměrně různorodý směr současného výzkumu nedemokratických režimů. Neméně různorodé jsou taktéž zpo̊soby, jakými se jednotlivé koncepty snaží vyrovnat s dosavadní kritikou vưči problematice hybridních režimů, a pochopitelně i úspěšnost těchto pokusů. V problematice odlišení od demokracie a autoritářství je možné konstatovat, že existují př́stupy, které se dosavadní kritikou príliš nezabývají a odlišnost akcentují především v jazykové rovině. Za takové je možné označit práci Heidrun Zinecker a trojice Mainwaring, Brinks a Peréz-Liñán. V obou př́padech je hybridních režimů deklarován jako svébytná kategorie, avšak tento aspekt není dostatečně aplikován $\mathrm{v}$ následné operacionalizaci. $\mathrm{U}$ autorů konceptu semidemokracie je tato snaha téměř až úsměvná, protože nejprve kriticky vystupují vůči užití termínů jako neliberální demokracie (Mainwaring, Brinks a Peréz-Liñán 2001: 41), aby poté svou vlastní kategorii nazvali semidemokracií. V nedávné práci Mainwaringa a Peréze-Liñána (2014) je navíc patrná jistá nejistota v tom, kam vlastně jejich koncept patří, i když stále deklarují, že jde o svébytnou kategorii. Oproti Zinecker, která raději užívá neutrální termín „částečný režim“, však alespoň vlastní východiska podrobují důkladnější reflexi. Někde na půli cesty zůstává práce Levitskyho a Waye. Ti se sice snaží některá svá

\footnotetext{
${ }^{25}$ Fitch se totiž ve své práci soustředí na to, zda má armáda právo veta v oblastech mimo armádní záležitosti (Fitch 1998: 42), kdežto Gilbert a Mohseni označují za př́pad poručnického režimu Chile nebo Brazílii po konci autoritářského režimu, protože zde armáda měla např. velkou volnost v rozpočtu či významné slovo v otázkách národní bezpečnosti, což naprosto neodpovídá Fitchově klasifikaci. Ten totiž ve své práci vychází z mimovropské tradice chápání vztahů mezi armádou a civilisty a není pro něj důležité, jestli civilisté ovládají armádu, ale jestli armáda neovládá civilisty. Autonomii armády v jistých oblastech tak jeho typologie neřeší (Fitch 1998: 42; Ruhl 2005: passim).
} 
starší východiska mírnit a precizovat, avšak stále je v jejich práci možné identifikovat řadu nejasností. Nejdál jsou v daném ohledu práce Wigella a dvojce Gilbert a Mohseni, kterým se minimálně v rovině odlišení od demokracie a autoritářství daří vytvořit relativně konzistentní a životaschopné koncepty přesně podle pravidel, která pro tvorbu konceptů doporučuje Goertz (2006).

V otázce vymezení volební soutěže je možné konstatovat, že mimo konceptu semidemokracie (pro který je analýza voleb stále nejzásadnějším definičním kritériem, avšak současně se jeho autoři př́liš nesnaží o další precizaci), usilují všechny ostatní koncepty o alespoň částečné odražení kritiky, která byla vedena vůči starším pojetím hybridních režimů. Práce Wigella a Zinecker sice provází $\mathrm{v}$ tomto bodě jistá vágnost, nicméně ta je $\mathrm{v}$ obou př́padech částečně eliminována tím, že se zmíněné koncepty při klasifikaci politického režimu nesoustředí pouze na analýzu voleb a s nimi bezprostředně souvisejících jevů. Nejlepší výsledky a pravděpodobně největší pokrok směrem k preciznímu vymezení je možné sledovat u práce Gilbert a Mohseniho. Levitsky a Way potom opět jako v předchozím prrípadě především zpřesňují své výchozí postoje.

Konečně problematika podkategorií a jejich hranic působí jako doposud zanedbané téma. Některé koncepty na jejich vymezení úplně rezignovaly a jiné provází nejasnosti, což je vidět především na kategorii poručnických režimů. Mimo práce Wiggela se navíc ostatní koncepty nesnaží pracovat s celým polem potenciálních režimů mezi demokracií a autoritářstvím a omezují se pouze na režimy, ve kterých existuje volební soutěž.

\section{Závěr}

Co nejpřesnější vymezení politických režimů nacházejících se mezi demokracií a autoritáŕstvím je jednou z největších výzev současného studia politických systémů. Ačkoliv se tomuto tématu $\mathrm{v}$ posledních několika desetiletích věnovalo značné množství energie, výsledky jsou stále nejednoznačné. Jedním z možných řešení se zdály být novější trichotomické klasifikace politických režimů, které slibovaly větší analytickou jasnost a jasné odlišení demokracie a autoritářství. Za účelem ověření této teze byly $\mathrm{v}$ předkládaném článku komparovány všechny významné současné trichotomické klasifikace hybridních režimů. Na základě provedené komparace je možné říci, že i když je na sledovaných konceptech poznat jistý kvalitativní posun co do schopnosti řešit nejzásadnější problémové oblasti identifikované $\mathrm{v}$ rámci kritiky, která byla vưči paradigmatu hybridních režimů vznesena, nejsou dosavadní výsledky tak povzbudivé, jak by se na první pohled mohlo zdát. Oproti stavu výzkumu krátce po roce 2002, kdy teorii hybridních režimů dominovaly především dichotomické koncepty odvozující povahu režimu téměr pouze $z$ faktu voleb, je dnes možné využít poměrně sofistikované a multidimenzionální klasifikace, jakou nabízejí např́ílad práce Gilbert a Mohseniho. Jednoznačně nejpoužívanější konceptem je však stále práce 
Levitskyho a Waye, která i přes snahu autorů o vylepšení některých slabších míst zůstává minimálně $\mathrm{v}$ očích některých výzkumníků problematická. Mimo evidentních pokroků je však třeba zmínit taktéž možná rizika. Ta jsou, vedle všech široce známých kritických bodů celé problematiky, ukryta především v podkategoriích jednotlivých konceptů, které jsou často vymezeny velmi vágně. Ne vždy uspokojivé vymezení podkategorií hybridních režimů navíc v souvislosti s ne zcela vyřešenými problémy předchozích prístupů odkrývá znepokojující pravdu o tom, že i po minimálně dvou desetiletích intenzivního teoretického úsilí je stanovení hranice mezi hybridními a nehybridními režimy problematické, a svým způsobem tak přetrvává problém, který měly právě trichotomické klasifikace řešit.

\section{Literatura}

Altman, David a Aníbal Peréz-Liñán (2002): „Assessing the Quality of Democracy: Freedom, Competitiveness and Participation in Eighteen Latin American Countries." Democratization 9(2): 85-100. DOI: 10.1080/714000256

Balík, Stanislav a Jan Holzer (2006): „Debata o hybridních režimech: Stručná rekapitulace pokusu o paradigmatickou změnu." Politologická revue 12(2): 5-29.

Beichelt, Timm (2012): „Forms of Rule in the Post-Soviet Space: Hybrid Regimes.“ In: Susan Stewart et. $\mathrm{Al}$ (eds.), President, Oligarchs and Bureaucrats: Forms of Rule in the Post-Soviet Space. London: Ashgate, 15-29.

Bogaards, Matthijs (2009): „How to classify hybrid regimes? Defective democracy and electoral authoritarianism.“" Democratization 16(2): 399-423. DOI: 10.1080/13510340902777800

Bunce, Valerie a Sharon L. Wolchick (2010): „Defeating Dictators: Electoral Change and Stability in Competitive Authoritarian Regimes.“ World Politics 62(1): 43-86. DOI: 10.1017/S0043887109990207

Carothers, Thomas (2002): „The End of the Transition Paradigm.“ Journal of Democracy 13(1): 5-21. DOI: 10.1353 /jod.2002.0003

Cassani, Andrea (2014): „Hybrid What? Partial consensus and persistent divergence in the analysis of hybrid regimes." International Political Science Review 35(2): 542-558. DOI: $10.1177 / 0192512113495756$

Castañeda, Jorge G. (1996): The Mexican Shock: Its Meaning for the United States. New York: New Press.

Collier, David a James E. Mahon (1993): „Conceptual Stretching Revisited: Adapting Categories in Comparative Analysis.“ American Political Science Review 87(4): 845-855. DOI: $10.2307 / 2938818$

Collier, David a Steven Levitsky (1997): „Democracy with Adjectives: Conceptual Innovation in Comparative Research." World Politics 49(3): 430-451. DOI: 10.1353/wp.1997.0009

Diamond, Larry (2002): „Thinking about hybrid regimes.“ Journal of Democracy 13(2): 21 35. DOI: $10.1353 /$ jod.2002.0025

Drahokoupil, Štěpán (2014): „Labyrintem hybridních režimů: př́stupy, kategorie a koncepty.“ Politologická revue 20(1): 3-26. 
Dvořáková, Vladimíra, Radek Buben a Jan Němec (2012): Que el pueblo mande! Levicové vlády, populismus a żmèny režimư v Latinské Americe. Praha: Doplněk.

Fitch, J. Samuel (1998): The Armed Forces and Democracies in Latin America. Baltimore: Johns Hopkins University Press.

Gandhi, Jennifer a Ellen Lust-Okar (2009): „Elections Under Authoritarianism.“ Annual Review of Political Science 12: 403-422. DOI: 10.1146/annurev.polisci.11.060106.095434

Garretón, Manuel A. (1989): La Redemocratization Política En Chile. Transición, inauguración y evolución. Santiago: Flasco.

Gilbert Leah (2012): State Mobilization Strategies and Political Competition in Hybrid Regimes. Disertační práce. Georgetown University, on-line (https://repository.library.georgetown.edu/handle/10822/557607)

Gilbert, Leah a Payam Mohseni (2011): „Beyond Authoritarianism: The Conceptualization of Hybrid Regimes." Studies in Comparative International Development 46(3): 270-297. DOI: 10.1007/s12116-011-9088-x

Goertz, Gary (2006): Social science concepts: A user's Guide. Princeton: Princeton UP.

Karl, Terry L a Philippe C. Schmitter (1991): „,What Democracy Is ... and Is Not.“Journal of Democracy 2(3): 75-88. DOI: 10.1353/jod.1991.0033

Karl, Terry L. (1986): „Imposing Consent: Electoralism Versus Democratization in El Salvador". In: Paul Drake a Eduardo Silva (eds): Elections in Latin America. San Diego: University of California, 9-36.

Karl, Terry L. (1995): „The Hybrid Regimes of Central America.“ Journal of Democracy 6(3): 72-86. DOI: $10.1353 /$ jod.1995.0049

Levitsky, Steven a James Loxton (2013): „Populism and competitive authoritarianism in the Andes." Democratization 20(1): 107-136. DOI: 10.1080/13510347.2013.738864

Levitsky, Steven a Lucan Way (2002): „The Rise of Competitive Authoritarianism.“ Journal of Democracy 13(2): 51-65. DOI: 10.1353/jod.2002.0026

Levitsky, Steven a Lucan Way (2010): Competitive Authoritarianism: Hybrid Regimes after the Cold War. Cambridge: Cambridge University Press.

Linz, Juan J. (1970): „An authoritarian regime: Spain.“ In: Erik Allard a Stein Rokkan (eds.), Mass Politics: studies in political sociology. Cambridge: Cambridge University Press, 251-283.

Mainwaring, Scott a Aníbal Peréz-Liñán (2014): Democracies and Dictatorships in Latin America: Emergence, Survival and Fall. New York: Cambridge University Press.

Mainwaring, Scott, David Brinks a Aníbal Peréz-Liñán (2001): „Classifying Political Regimes in Latin America, 1945-1999.“ Studies in Comparative International Development 36(1): 37-65. DOI: 10.1007/BF02687584

Mainwaring, Scott, David Brinks a Aníbal Peréz-Liñán (2007): „Classifying Political Regimes in Latin America, 1945-2004.“ In: Gerardo L. Munck (ed): Regimes and Democracy in Latin America: Theories and Methods. New York: Oxford University Press, 199-230.

Marschall Monty G. et. al. (2012): Polity IV Project. Political Regime Characteristic and Transitions 1800-2012. Dataset Users's Manual. Centre for Systematic Peace.

Merkel, Wolfgang (1999): „Defective Democracies.“ Working Paper of Juan March Institute, No. $1999 / 132$.

Merkel, Wolfgang (2004): „Embedded and defective democracies.“ Democratization 11(5): 33-58. DOI: 10.1080/13510340412331304598 
Merkel, Wolfgang (2010): „Are Dictatorships returning? Revisiting the democratic rollback hypothesis." Contemporary Politics 16(1): 17-31. DOI: $10.1080 / 13569771003593839$

Miller, Michael K. (2012): „Electoral authoritarianism and democracy: A formal model of regime transitions." Journal of Theoretical Politics 25(2): 153-181. DOI: $10.1177 / 0951629812460122$

Morgenbesser, Lee (2014): „Elections in Hybrid Regimes: Conceptual Stretching Revived.“ Political Studies 62(1): 21-36. DOI: 10.1111/1467-9248.12020

Munck, Gerardo L. (2001): „The regime question: theory building in democracy studies.“ World Politics 54(1): 119-144. DOI: 10.1353/wp.2001.0025

Munck, Gerardo L. (2006): „Drawing boundaries: how to craft intermediate regime categories." In: Andreas Schedler (ed.), Electoral Authoritarianism. The Dynamics of Unfree Competition. London: Lynne Rienner Publishers, 7-40.

O`Donnell, Guillermo (1994): „Delegative Democracy.“ Journal of Democracy 5(1): 55-69. DOI: $10.1353 /$ jod.1994.0010

Ottaway, Marina S. (2003): Democracy Challenged: The Rise of Semi-Authoritarianism. Washington DC: Carnegie Endowment for International Peace.

Przeworski, Adam et. al. (2000): Democracy and Development. Political Institutions and Well-Being in the World, 1950-1990. Cambridge: Cambridge UP

Ptáčník, Jan (2012): „Perspektivy využití Linzovy metodologie pro výzkum nedemokracie." Strédoevropské politologické studie 14(2-3) s. 315-336.

Raun, Alo (2013): „How to Survive Western Democratising Pressure?“ Studies of Transitions States and Societies 5(1): 85-88.

Rüb, Friedbert W. (2002): „Politikwissenschaftliches Chamäleon oder neuer Regimetypus? Begriffliche und konzeptionelle Überlegungen zum neuen Pessimismus in der Transitologie." In: Petra Bendel a Aurel Croissant (eds): Zwischen Demokratie und Diktatur. Zur Konzeption und Empirie demokratischer Granzonen. Opladen: Leske + Budrich, 99-118.

Ruhl, J. Mark (2005): „The Guatemala Military Since the Peace Accords: The Fate of Reform Under Arzú and Portillo." Latin American Politics and Society 47(1): 55-85. DOI: 10.1353/lap.2005.0013

Sartori, Giovanni (1970): „Concept Misformation in Comparative Politics.“ American Political Science Review 64(4): 1033-1055. DOI: 10.2307/1958356

Sartori, Giovanni (1976): Parties and party systems: Framework for Analysis. Cambridge: Cambridge University Press.

Schedler, Andreas (2006): „The Logic of Electoral Authoritarianism.“ In: Andreas Schedler (ed.), Electoral Authoritarianism. The Dynamics of Unfree Competition. London: Lynne Rienner Publishers, 1-22.

Stepan, Alfred (1988): Rethinking Military Politics: Brazil and the Southern Cone. Princeton: Princeton University Press.

Valenzuela, Juan R. (1990): „Democratic Consolidation in Post-Transitional Settings: Notion, Process and Facilitating Conditions." Working Paper of Kellogg Institute, No. 1990/150.

Wahman, Michael, Jan Teorell a Axel Hadenius (2013): „Authoritarian regime types revisited: update data in comparative perspective." Contemporary Politics 19(1): 19-34. DOI: $10.1080 / 13569775.2013 .773200$ 
Wigell, Mikael (2008): „Mapping „hybrid regimes“. Regime types and concepts in comparative politics.“ Democratization 15(2): 230-250. DOI: 10.1080/13510340701846319

Zakaria, Fareed (1997): „The Rise of Illiberal Democracy.“ Foreign Affairs 76(6): 22-43. DOI: $10.2307 / 20048274$

Zinecker, Heidrun (2009): „Regime-Hybridity in Developing Countries: Achievements and Limitations of New Research on Transitions." International Studies Review 11(2): 302_ 331. DOI: $10.1111 /$ j.1468-2486.2009.00850.x

\section{Hybrid Regimes as an Independent Type of Political Regime: A Comparison of Selected Approaches}

\section{SUMMARY}

The debate about hybrid regimes has been one of the most interesting in the field of nondemocratic regime research over the last two decades. One of the most visible weaknesses of the hybrid regimes paradigm appears to be the unclear position that hybrid regimes occupy on the scale between democratic and authoritarian regimes. Many authors view considering hybrids as a category of political regime sui generis, without regard to their democratic or authoritarian character, as an adequate solution to this problem. The aim of this text is to contribute to this debate by means of a rather neglected topic - the comparison of existing trichotomic classifications of hybrid regimes -, motivated by the question of whether and how these classifications succeed in dealing with the problems of hybrid regime theory. If they failed, it would mean a problem for the whole hybrid theory discourse, which often draws its legitimacy from the efforts to eliminate such problems. For the purpose of this comparison, I will deal with the concepts and classifications presented by Mainwaring, Brinks and Pérez-Liñán (2001), Wigell (2008), Zinecker (2009), Levitsky and Way (2010), and Gilbert and Mohseni (2011).

The criteria for my comparison are based on the main tenets of criticism of hybrid regime theory. First, I deal with the theoretical construction of concepts and arguments based on the need to distinguish hybrid regimes from both democratic and authoritarian ones. Second, I examine hybrid regime theories' conceptualizations of electoral competition, which used to be among the most problematic aspects of past theories of hybrid regimes. Third, I deal with the manner in which individual theories try to map and divide the "grey zones" between different types and subtypes of regimes. The various subtypes of hybrid regimes have never been the subject of systematic investigation and discussion, which has led to a certain vagueness and confusion in their application - some of them are usually viewed as categorically different types, whereas they display a tendency to overlap.

The comparison shows that despite the common overall aim (to conceptualize hybrid regimes as a category of regimes sui generis), the hybrid regime theory discourse represents a colourful and heterogeneous family of approaches, with many diverse 
attempts and differing levels of success on the part of various authors in dealing with the aforementioned criticisms. With regard to attempts to clearly establish the boundary between democracy and authoritarianism, there are some concepts which do not seem to reflect on any of the criticisms and accentuate the differences mostly at the rhetorical level, e.g. works by Zinecker, and Mainwaring, Brinks and Pérez-Liñán. Both conceptions attempt to frame the hybrid regime as a self-standing type, however fail to operationalise its uniqueness. In comparison with Zinecker, the latter group of authors at least present a formidable critical reflection on their own assumptions. Levitsky's and Way's theory stops short of achieving its goals: The authors try hard to overcome the problems arising from their earlier arguments, but are still unable to eliminate all the ambiguities. In contrast, the works of Wigell and Gilbert and Mohseni appear to be as close as possible to their goal, presenting relatively consistent and useful concepts, at least with regard to the distinction between hybrids, democracy and authoritarianism .

In the authors' attempts to deal with the problem of the conceptualization of electoral competition, all of the presented concepts except semi-authoritarianism appear to deal to some extent with all the basic tenets of the respective critique. Though the arguments put forward by Wigell and Zinecker still exhibit some vague contours, they try to overcome this vagueness by constructing their theory in such a way that it is able to utilize sources of explanation from outside the world of electoral competition. Levitsky and Way mostly present a refined version of their earlier concepts, trying to deal with the most important parts of previous criticisms. Gilbert and Mohseni's work represents, however, the greatest progress in hybrid regime theory, presenting the best results.

The overpopulated world of analytical categories and subcategories still appears to be rather short on systematic development of the respective conceptions. Some authors do not even try to define such categories; with some others, there are some uncertainties with regard to their use (e.g. tutelary regimes). Furthermore, most of the aforementioned theories fail to integrate the whole field of regimes into the scale between democracy and authoritarianism and focus only on regimes with some form of electoral competition.

In comparison with earlier discussions of hybrid regimes, dominated mostly by dichotomic concepts almost exclusively based on the analysis of electoral processes, theories of hybrid regimes have evolved into multidimensional and sophisticated analytic frameworks, with the best example represented by Gilbert and Mohseni's theory. The most cited theory, however, remains that of Levitsky and Way, though for some researchers it still fails to address some critical issues. In addition to obvious progress in the debate about hybrids, some caveats have to be included, especially with regard to the ambiguous or absent definitions of some of the subcategories of regimes, which reveals that even after decades of discussions, the problem of the unclear boundary between hybrids and non-hybrids still remains. 